\title{
PENGARUH PERENDAMAN BENIH PADA BERBAGAI JENIS LARUTAN URIN TERHADAP DAYA TUMBUH KECAMBAH KALIANDRA (Calliandra calothyrsus)
}

\author{
Tri Ida Wahyu Kustyorini, Permata Ika Hidayati \\ Fakultas Peternakan \\ Universitas Kanjuruhan Malang \\ Email: triida@unikama.ac.id
}

\begin{abstract}
Abstrak
Penelitian ini bertujuan untuk mengetahui hasil pengaruh perendaman benih pada berbagai jenis larutan urin terhadap daya tumbuh kecambah kaliandra (Calliandra calothyrsus). Materi yang digunakan dalam penelitian ini adalah benih kaliandra sebanyak 100 gr, urin sapi, kambing dan domba sebanyak @1 liter. Metode yang digunakan dalam penelitian ini adalah eksperimental lapang berdasarkan Rancangan Acak Lengkap (RAL) yang terdiri atas 5 perlakuan dan 3 ulangan. Perlakuan penelitian terdiri dari P0 (perlakuan kontrol/tanpa perendaman), P1 (perendaman pada air) dan perlakuan eksperimental dengan perendaman pada berbagai jenis urin dengan konsentrasi 10\%, yakni, P2 (larutan urin sapi), P3(larutan urin kambing) dan P4 (larutan urin domba). Variabel yang diamati dalam penelitian ini yaitu daya tumbuh kecambah kaliandra yang meliputi persentase perkecambahan, tinggi bibit, persentase benih mati, dan persentase kecambah normal. Data yang diperoleh dianalisis dengan menggunakan analisis sidik ragam anova tunggal dengan bantuan aplikasi SPSS for Windows,apabila terdapat pengaruh maka dilanjutkan dengan uji. Perendaman pada urin sapi memberikan nilai terbaik pada persentase kecambah $(88,33 \%)$, tinggi bibit $(5,67 \pm 0,57) \mathrm{cm}$, persentase benih mati terendah $(11,67 \pm 3,51 \%)$, dan persentase kecambah normal $(91,67 \pm 1,52 \%)$. Kesimpulan dari hasil penelitian yaitu perendaman benih pada urin sapi memberikan pengaruh terbaik terhadap daya tumbuh kecambah kaliandara (Calliandra calothyrsus).
\end{abstract}

Kata kunci: Uji, perkecambahan, urin, kaliandra

\section{EFFECT OF SEED IMMERSION IN VARIOUS TYPES OF URIN SOLUTIONS ON THE GROWTH OF KALIANDRA (Calliandra calothyrsus)}

\begin{abstract}
This study aims to determine the effect of seed immersion on various types of urine solution on the growth of Calliandra calothyrsus. The material used in this study was 100 grams of calliandra seed, cow urine, goat urine and sheep urine. The method used in this study was a field experiment based on a Completely Randomized Design (CRD) consisting of 5 treatments and 3 replications. The treatment consisted of P0 (control / no soaking treatment), P1 (immersion in water) and experimental treatment with soaking in various types of urine with a concentration of 10\%, namely, P2 (cow urine solution), P3 (goat urine solution) and P4 (sheep urine solution). The variables observed in this study were the growth of kaliandra sprouts which included germination percentage, seed height, percentage of dead seeds, and the percentage of normal sprouts. The data obtained were analyzed using a single ANOVA variance analysis with the help of the SPSS for Windows application, if there was an influence then proceed with the test. Immersion in cow urine gave the best value in the percentage of sprouts $(88.33 \%)$, seedling height $(5.67 \pm 0.57) \mathrm{cm}$, the lowest percentage of dead seeds $(11.67 \pm 3.51 \%)$, and the percentage of normal sprouts ( $91.67 \pm$ $1.52 \%$ ). The conclusion of the research results is that the immersion of seeds in cow urine gives the best effect on the power of kaliandara sprouts (Calliandra calothyrsus).
\end{abstract}

Keywords: Seed germination test, urine solutions, Calliandra

\section{PENDAHULUAN}

Kaliandra merupakan salah satu jenis leguminosa yang banyak di budidayakan oleh peternak. Benih kaliandra mempunyai sifat dormansi yang lama, yang disebabkan oleh kulit benih yang keras, sehingga untuk memecahkannya diperlukan suatu 


\section{Jurnal Sains Peternakan}

Vol 6, No 1, Juni 2018, pp: 47-52

ISSN 2579-4450

perlakuanpendahuluan tertentu. Kulit benih keras pada umumnyamenghambat perkecambahanwalaupun disemaikan padakondisi perkecambahan yang optimal. Salah satu upaya pemutusan dormansi yakni dengan perendaman pada larutan zat pengatur tumbuh. Perendaman benih pada larutan zat pengatur tumbuh (ZPT) dilakukan untuk menambah kadar hormon yang telah ada,dan juga untuk meningkatkan daya kecambah benih (Munandar, 2004). Perkecambahan benih dorman dapat didorong dengan memberikan zat pengatur tumbuh seperti Auksin, Sitokinin, Giberelin (Yunita, 2011). Urin ternak merupakan salah satu substrat yang mengandung Auksin dan Asam Giberelin(GA) serta Kinetin(Astutik, 2013). Menurut Nasution (2014) urin ternak secara terbatas dapat menggantikan fungsi zat pengatur tumbuh sintesis yang diperlukan untuk memacu berakarnya tanaman kaliandra. perlakuan perendaman benih pada larutan urin ternak diharapkan dapat memecahkan dormansi danmeningkatkan persentase perkecambahan pada benih tersebut.Perkecambahanmerupakan tahapan awal dari proses pertumbuhan dan perkembangan pada tumbuhan berbiji seperti tanaman kaliandra. Embrio di dalam endosperma biji yang semula berada pada kondisi dorman mengalami sejumlah perubahan fisiologis yang menyebabkan berkembang dan menjadi tumbuhan muda. Endosperma berfungsi sebagai penyedia cadangan energi bagi embrio dalam proses perkecambahan, mengandung protein albumin (protein yang larut dalam air), karbohidrat dan lemak (Anonim, 2011). Endosperma dapat berkecambah apabila didukung oleh faktor-faktor eksternal maupun internal, seperti keadaan biji kaliandra, permeabilitas kulit biji dan tersedianya air disekeliling biji (Aprilisa, 2011). Untuk mencegah rendahnya daya kecambah biji maka dipilih biji yang berasal dari polong yang telah benar-benar masak.

Urin adalah zat-zat yang disekresikan melalui ginjal, zat zat yang di dapat di dalamnya adalah zat zat makanan yang sudah dicerna, kemudian diserap dan bahkan telah dimetabolisme sel-sel tubuh kemudian dikeluarkanmelalui ginjal dan saluran urin. Urin mempunyai zat pengatur tumbuh dan mempunyai sifat penolak hama atau penyakit tanaman (Wina, 2013). Menurut Maryeni (2011) Menyatakan bahwa urin sapi dapat digunakan sebagai sumbera uksin. Urin ini harus diencerkan dengan air bersih sehingga diperoleh kosentrasi 51\% pupuk kadang cair selain dapat dikerja cepat, juga mengandung fitohormon auksin tertentu yang nyata dapat merangsang perkembangan tanaman.

Uji daya kecambah merupakan salah satu metode yang digunakan untuk mengetahui hasil perkecambahan benih sebelum ditanam dilapangan (Desmawan dkk, 2011). Pengujian daya kecambah benih adalah menguji kemampuan benih berkecambah secara normal dari sejumlah benih pada jangka waktu yang telah ditentukan. Berdasarkan uraian diatas perlu dilakukan penelitian tentang pengaruh perendaman pada berbagai jenis urin terhadap daya tumbuh kecambah kaliandra (Calliandra calothyrsus).

\section{MATERI DAN METODE}

Materi Penelitian yang digunakan adalah benih kaliandra sebanyak 100 gr dan urin ternak (sapi, kambing, domba) sebanyak masing-masing 1 liter.

Metode yang digunakan dalam penelitian ini adalah eksperimental lapang berdasarkan rancangan acak lengkap (RAL) yang terdiri atas 5 perlakuan dan 3 ulangan sehingga total percobaanadalah 15 unit percobaan. Perlakuan penelitian terdiri dari perlakuan kontrol tanpa perendaman dan perlakuan eksperimental dengan berbagai juenis larutan urin dengan konsentrasi $10 \%$.

Perlakuan penelitian yang dilaksanakan adalah sebagai berikut:

P0: kontrol (tanpa peredaman)

P1: perendaman pada air

P2: perendaman pada larutan urin sapi

P3: perendaman pada larutan urin kambing

P4: Perendaman pada larutan urin domba. 


\section{Jurnal Sains Peternakan}

Vol 6, No 1, Juni 2018, pp: 47-52

ISSN 2579-4450

Variabel yang diamati dalam penelitian ini meliputi Persentase perkecambahan benih, tinggi bibit, persentase benih mati, dan persentase kecambah normal.

Data yang diperoleh selama pengamatan dianalisis dengan menggunakan analisis sidik ragam anava tunggal dengan bantuan aplikasi SPSS for Windows. Apabila pada hasil analisa menunjukkan adanya perbedaan pada perlakuan dengan taraf signifikansi 0,05 maka dilanjutkan dengan uji duncanuntuk menunjukkan perbedaan pada masing-masing perlakuan.

\section{HASIL DAN PEMBAHASAN}

Rataan hasil penelitian tentang uji daya kecambah benih kaliandra (Calliandra calothyrsus) pada berbagai larutan urin ternak disajikan pada tabel 1.

Tabel 1. Rataan hasil uji daya kecambah benih kaliandra(Calliandra calothyrsus)

\begin{tabular}{lrrrr}
\hline Perlakuan & $\begin{array}{c}\text { Persentase } \\
\text { Kecambah }(\%)\end{array}$ & $\begin{array}{c}\text { Tinggi Bibit } \\
(\mathrm{cm})\end{array}$ & $\begin{array}{c}\text { Persentase } \\
\text { Benih Mati }(\%)\end{array}$ & $\begin{array}{r}\text { Persentase Kecambah } \\
\text { Normal }(\%)\end{array}$ \\
\hline $\mathrm{P}_{0}$ & $50,67 \pm 6,11^{\mathrm{a}}$ & $4,67 \pm 0,57$ & $49,33 \pm 6,11^{\mathrm{d}}$ & $80,00 \pm 3,46^{\mathrm{a}}$ \\
$\mathrm{P}_{1}$ & $70,67 \pm 3,05^{\mathrm{b}}$ & $5,67 \pm 0,57$ & $29,33 \pm 3,05^{\mathrm{c}}$ & $83,00 \pm 7,00^{\mathrm{ab}}$ \\
$\mathrm{P}_{2}$ & $88,33 \pm 3,51^{\mathrm{d}}$ & $5,67 \pm 0,33$ & $11,67 \pm 3,51^{\mathrm{a}}$ & $91,67 \pm 1,52^{\mathrm{c}}$ \\
$\mathrm{P}_{3}$ & $81,67 \pm 2,08^{\mathrm{cd}}$ & $5,00 \pm 1,00$ & $18,33 \pm 2,08^{\mathrm{ab}}$ & $90,00 \pm 4,00^{\mathrm{bc}}$ \\
$\mathrm{P}_{4}$ & $80,33 \pm 2,52^{\mathrm{c}}$ & $4,33 \pm 0,57$ & $19,67 \pm 2,51^{\mathrm{b}}$ & $91,33 \pm 1,52^{\mathrm{c}}$ \\
$P$-Value & $\mathrm{P}<0,01$ & $\mathrm{P}>0,05$ & $\mathrm{P}<0,01$ & $\mathrm{P}<0,05$ \\
\hline
\end{tabular}

Ket: Notasi yang berbeda pada kolom yang sama memberikan pengaruh terhadap uji daya kecambah benih kaliandra (Calliandra calothyrsus)

\section{Persentase Perkecambahan}

Berdasarkan hasil analisis statistik menunjukkan bahwa perendaman benih pada berbagai jenis larutan urin memberikan pengaruh yang sangat nyata $(\mathrm{P}<0,01)$ terhadap persentase kecambah benih. Persentase perkecambahan benih tertinggi terjadi pada $\mathrm{P}_{2}$ (perendaman pada larutan urin sapi) dengan nilai $88,33 \pm 3,51 \%$, namun tidak berbeda nyata dengan $\mathrm{P}_{3}$ (perendaman pada larutan urin kambing) yaitu sebesar $81,67 \pm 2,08 \%$. Hal ini dikarenakan pada larutan urin kambing dan sapi memiliki kadar giberelin dan auksin yang lebih yakni pada urin sapi 243 ppm dan 503 ppm dan pada urin kambing 43 ppm dan 1013 ppm (Nasution, 2014).

Urin ternak merupakan zat pengatur tumbuh jenis auksin. Beberapa keunggulan urin ternak diantarannya mempunyai kandungan unsur hara yang lengkap diantarannya $\mathrm{N}$, $\mathrm{P}, \mathrm{K}, \mathrm{Ca}, \mathrm{Fe}, \mathrm{Mn}, \mathrm{Zn}$, dan $\mathrm{Cu}$. Pemberian urin sapi dapat memberikan pengaruh pada pertumbuhan akar tanaman. Urin ternak umumnya memiliki kandungan hara yang lebih tinggi dibandingkan kotoran padat, sehingga pada aplikasinya tidak sebanyak penggunaan pupuk organik padat (Yunita, 2011)

Fitohormon adalah senyawa organik yang dalam konsentrasi rendah $(<1 \mathrm{~mm})$ mampu mendorong, menghambat, atau secara kualitatif merubah pertumbuhan dan perkembangan tanaman (Nasution, 2014). Dalam urin sapi dan kambing juga mengandung sejumlah auksin yang berasal dari makanannya berupa tumbuhan, terutama dari ujung tanaman seperti tunas, kuncup daun, kuncup bunga dan lain-lain, dimana tumbuhan tersebut di dalam sistem pencernaannya diolah sedemikian rupa sehingga auksin ikut bersama dengan zat-zat yang ada pada tumbuhan tersebut, karena auksin tidak terurai dalam tubuh, maka auksin dikeluarkan sebagai filtrat bersama-sama dengan urin. Auksin sebagai salah satu hormon tumbuhan bagi tanaman mempunyai peranan terhadap pertumbuhan dan perkembangan tanaman. Dilihat dari segi fisiologi, hormon ini berpengaruh terhadap pembelahan sel, pemanjangan sel hingga terjadi pembentukan akar, batang, daun, dahan, ranting, bunga dan buah (Naswir, 2003).

Persentase perkecambahan terendah pada perlakuan $\mathrm{P}_{0}$ (tanpa perendaman/kontrol) yaitu sebesar $50,67 \%$. Hal ini dikarenakan sifat dormansi benih 


\section{Jurnal Sains Peternakan}

Vol 6, No 1, Juni 2018, pp: 47-52

ISSN 2579-4450

tetap berlanjut, sebagaimana pernyataan Lita (2010) yang menyatakan bahwa dormansi fisik dapat disebabkan oleh impermiabilitas kulit biji terhadap air. Dormansi pada benih dapat disebabkan oleh keadaan fisik dari kulit biji ataupun keadaan fisiologis dari embrio atau kombinasi dari kedua kedaan tersebut. Sebagai contoh kulit biji yang impermeabel terhadap air dan gas sering dijumpai pada benih-benih dari famili leguminosae.Faktorfaktor yang menyebabkan hilangnya dormansi pada benih sangat bervariasi tergantung pada jenis tanaman dan tentu saja tipe dormansinya, antara lain yaitu: karena temperatur yang sangat rendah di musim dingin, perubahan temperatur yang silih berganti, menipisnya kulit biji, hilangnya kemampuan untuk menghasilkan zat-zat penghambat perkecambahan, adanya kegiatan dari mikroorganisme (Aisah dan Herianto, 2016).

\section{Tinggi Bibit}

Berdasarkan hasil analisa sidik ragam menunjukkan bahwa perendaman benih pada berbagai jenis larutan urin ternak tidak berpengaruh $(\mathrm{P}>0,05)$ terhadap tinggi benih. Kisaran tinggi benih pada semua perlakuan antara 4,33cm-5,67cm. Hal ini dikarenakan proses pemeliharaan bibit setelah tumbuh pada semua perlakuan sama. Yudono (2006) menyatakan bahwa pertumbuhan bibit di pengaruhi oleh dua faktor yaitu faktor internal (genetik dan hormonal) dan faktor eksternal (kematangan biji dan lingkungan). Dalam hal ini lingkungan pada semua perlakuan sama, sehingga pertumbuhan bibit juga memberikan hasil yang relatif sama.

\section{Persentase Benih Mati}

Berdasarkan hasil analisis statistik menunjukkan bahwa perendaman benih pada berbagai larutan urin memberikan pengaruh sangat nyata $(\mathrm{P}<0,01)$ terhadap persentase benih mati. Persentase benih mati tertinggi pada perlakuan $\mathrm{P}_{0}$ (tanpa perendaman) yaitu sebesar $49,33 \pm 6,11 \%$. Hal ini dikarenakan benih masih berada dalam masa dormansi ketika mulai ditanam. Sehingga kulit arinya pun masih kuat, sehingga sulit di tembus oleh akar. Persentase benih mati terendah pada perlakuan $\mathrm{P}_{2}$ (perendaman pada larutan urin sapi) senilai $11,67 \pm 3,51 \%$ namun tidak berbeda nyata dengan perlakuan $\mathrm{P}_{3}$ (perendaman pada larutan urin kambing) yaitu $18,33 \pm 2,08 \%$. Hal ini dikarenakan pada larutan urin kambing dan sapi memiliki kadar giberelin dan auksin yang cukup tinggi yakni pada urin sapi $243 \mathrm{ppm}$ dan $503 \mathrm{ppm}$ dan pada urin kambing 43 ppm dan 1013 ppm (Nasution,2014).

Hasil persentase benih mati berbanding terbalik dengan hasil persentase perkecambahan benih, karena benih mati merupakan benih yang tidak berkecambah pada saat uji daya kecambah. Penurunan persentase kematian benih pada perlakuan P0 sampai P4 diduga karena urin sapi mengandung fitohormon yang dapat merangsang perkecambahan pada benih, sehingga benih mati lebih sedikit dari benih yang berkecambah.

\section{Kecambah Normal}

Berdasarkan hasil analisis statistik menunjukkan bahwa perendaman dalam berbagai larutan urin ternak memberikan pengaruh yang nyata $(\mathrm{P}<0,05)$ terhadap hasil persentase kecambah normal, Berdasarkan hasil perhitungan rata-rata persentase kecambah normal terlihat bahwa hasil tertinggi mencapai rata-rata $91,67 \%$ pada perlakukan $\mathrm{P}_{2}$ dengan perendaman pada larutan urin sapi.

Berdasarkan hasil yang didapat pada persentase kecambah normal terdapat fluktuasi nilai persentase kecambah normal yang naik turun, dan dari hasil analisa sidik ragam menunjukkan pengaruh yang nyata $(\mathrm{P}<0,05)$ terhadap hasilpersentase kecambah normal. Hal ini menunjukkan bahwa perendaman benih dalam larutan urin sapi 


\section{Jurnal Sains Peternakan}

Vol 6, No 1, Juni 2018, pp: 47-52

ISSN 2579-4450

berpengaruh terhadap persentase kecambah normal. Hal ini dikarenakan kadar auksin dan giberelin pada masing-masing jenis urin memiliki kadar yang berbeda.

Urin merupakan sumber ekskresi $\mathrm{N}$ yang penting artinya dalam hubungan tanah dengan hewan. Urin merupakan Sumber unsur $\mathrm{N}, \mathrm{K}, \mathrm{Mg}$ yang penting. Urin sapi merupakan salah satu fitohormon alami yang mengandung hormon dari golongan IAA, Giberilin dan Sitokinin. Secara fisiologis fitohormon berfungsi dalam perkembangan dan diferensiasi sel yang dapat memacu pertumbuhan organ-organ tanaman, seperti akar, tunas dan meristem apikal lainnya. Respon fitohormon tersebut akan berlangsung pada konsentrasi yang rendah dan bila diberikan dalam konsentrasi yang tinggi maka fitohormon tersebut akan bersifat merusak atau penghambat pertumbuhan (Adrian dan Murniati, 2007)

\section{KESIMPULAN}

Berdasarkan hasil penelitian dapat disimpulkan bahwa perendaman benih pada berbagai jenis urin terhadap daya tumbuh kecambah kaliandra (Calliandra calothyrsus) larutan urin sapi memberikan nilai persentase perkecambahan yang terbaik $(88,33 \%)$, persentase benih mati terendah $(11,67 \%)$ dan Persentase kecambah normal terbaik $(91,67 \%)$.

\section{UCAPAN TERIMA KASIH}

Ucapan terima kasih disampaikan kepada semua pihak terutama Laboratorium Lapang Fakultas Peternakan Universitas Kanjuruhan Malang yang telah banyak membantu sejak persiapan hingga terselenggaranya penelitian ini dengan baik.

\section{DAFTAR PUSTAKA}

Anonim, 2011. Kunci Sukses Memperbanyak Tanaman Kaliandra. Agromedia Pustaka: Jakarta. Cet. Ke-3 2008.

Aprilisa, 2011.Tata cara pengujian benih. Balai Perbenihan Tanaman Hutan, Bandung.

Astutik, 2013. Pengaruh zat Giberelin Terhadap Perkecambahan Biji Kaliandra. Universitas Airlangga.

Aisah Dan Harrianto, 2016. Faktor-faktor Penghambat Perkecambahan Benih.

Bagod, 2006. Drying treatment drastically affects feed evaluation and feed quality with certain tropical forage species. Animal Feed Science and Technology 22:69-78.

BTP (Balai Teknologi Perbenihan). 2000. Pedoman Standarisasi Pengujian Mutu Fisik dan Fisiologis Benih Tanaman Hutan. Publikasi Khusus. Vol.2 No 4. Balai Teknologi Perbenihan, Badan Litbang Kehutanan dan Perkebunan. Bogor

Chamberlain, 2001.Genetic improvement of Calliandra calLothyrsus. In DO Evans and LT Szott, eds. Nitrogenfixing trees for acid soils. Nitrogen Fixing Tree Research Reports (Special issue). Winrock International. Morrilton, Arkansas, USA.p.250257. 


\section{Jurnal Sains Peternakan}

Vol 6, No 1, Juni 2018, pp: 47-52

ISSN 2579-4450

Desmawan dkk.2011. Pengaruh Suhu dan Lama Perendaman Benih Terhadap Perkecambahan Dan Pertumbuhan Awal Kaliandra (calliandracalothyrsus). Universitas Gajah Mada. Yogyakarta.

Deni, 2015.Efisiensi Serapan Nitrogen Tiga Varietas Kedelai Dengan Pemupukan Nitrogen Dan Penambahan Rhizobium Pada Tanah Dengan Status Hara N Rendah. Jurnal Pertanian Tropik. 2 (2):140-147.

Hidayat et.al, 2006 Culture and uses of Calliandracalothyrsus in Indonesia.In D0 Evans, ed. International Workshop on the Genus Calliandra.Forest, Farm, Dan Community Tree, Research Reports (Special issue). Winrock International. Morrilton, Arkansas, USA. p. 101 - 07.

Kementrian Energi dan Sumber daya Mineral 2006. Calliandra serie Racemosae. Taxonomic information, OFI seed collections, trial design. Oxfor Forestry Institute.

IFSP. 2000. Visual presentationof extension material. Indonesia Forest Seed Project, Bandung.

Munandar, 2004. Respon Perkecambahan Biji Kaliandra (Calliandra calothyrsus) Terhadap Lama Perendaman Dengan Asam Nitrat $\left(\mathrm{HNO}_{3}\right)$. Skripsi. Medan: F. Pertanian USU.

Mayerni, 2011. Pengaruh Beberapa Konsentrasi Giberelin Terhadap Pertumbuhan Bibit Kaliandra (Calliandra calothyrsus). Universitas Andalas Padang.

Murniati, E. 2013. Fisiologi Perkecambahan dan Dormansi Benih (Dasar Ilmu dan Teknologi Benih). IPB Press.

Michael. 2004. A phylogeny of legumes based on analysis of the plastid gene resolves manywelln supported subclades within thef. Jurnal Botani Amerika. 91(11):1846 1862.

Naswir, 2003.Pemanfaatan Urin Sapi yang Difermentasi Sebagai Nutrisi Tanaman. Institut Pertanian Bogor.

Nasution,L.W. 2014. Percepatan Perkecambahan dan Pertumbuhan Kaliandra (Calliandra calothyrsus) Akibat Perendaman Pada Urine Hewan dan Pemotongan Benih. Skripsi. Medan: F. Pertanian USU.

Nurfadidah, 2013. Pengaruh Sumber dan Konsentrasi Nitrogen terhadap Pertumbuhan dan Perkembangan Biji Dendrobium laxi florum J.J Smith secara In Vitro.Jurnal Sains dan Seni Pomits. 2 (1): 26 - 29.

Purnobasuki, 2011. Produksi dan pemanfaatan kaliandra (Calliandra calothyrsus): Pedoman lapang.International Centre 